\title{
Disproportionate Collapse Mitigation in Tall Mass Timber Buildings
}

\author{
Hossein Daneshvar ${ }^{1 *}$ and Ying Hei Chui ${ }^{2}$ \\ ${ }^{1}$ Post Doctoral Fellow, Department of Civil and Environmental Engineering, University of \\ Alberta, Canada \\ ${ }^{2}$ Professor, Department of Civil and Environmental Engineering, University of Alberta, Canada \\ *Corresponding author's e-mail: hossein.daneshvar@ualberta.ca
}

\begin{abstract}
Tall buildings are a unique type of structure with their own characteristic behaviour. They are most often occupied by a large number of people; therefore, their damage, loss of functionality, or, in worst case scenario, collapse will lead to catastrophic consequences. There are methodologies intended to provide structural integrity or increase structural robustness in tall buildings, thereby making structures resistant to disproportionate collapse, which is characterized by a cascading progression of damage that is not proportionate to the initial failure. Tall buildings are commonly constructed with steel and concrete. As a result, most of the attempts at providing structural integrity are dedicated to mitigating the effect of disproportionate collapse in the steel and concrete members, connections, and their systems. On the other hand, with rising demand for new sustainable buildings in urban areas, tall mass timber buildings have attracted increased attention nationally and internationally. Ease of modularization and offsite construction is one of the greatest advantages of using mass timber in tall building construction in the congested urban areas of major cities. A major challenge facing the engineering community is the lack of research studies regarding the structural robustness required to mitigate the potential of disproportionate collapse. The current study seeks to begin the process of understanding the behaviour of mass timber components and assemblages, and make recommendations regarding their performance and possible means to mitigate the occurrence of disproportionate collapse. These recommendations would lead to safer structural performance in the event of localized damage that has the potential to spread to a disproportionately large part of the structure.
\end{abstract}

\section{KEYWORDS}

Mass Timber Panels (MTPs); Glulam, Glue laminated timber (GLT); Cross laminated timber (CLT); Robustness; Structural Integrity; Disproportionate Collapse, Progressive collapse; Column removal scenario (CRS); Balloon construction; Lateral load resisting system (LLRS); Vertical load resisting system (VLRS); Connections

\section{INTRODUCTION}

There are a few design methodologies and techniques aimed at providing structural integrity by increasing the structural robustness in order to mitigate the probability of disproportionate collapse, which is characterized by a cascading progression of damage that is not proportionate to the initial failure. Most of the methods and techniques are well-developed for steel and concrete structures since the majority of high-rise buildings are built using steel and concrete. Considering 
the rising demand for new sustainable buildings in highly populated urban areas, interest in highrise mass timber buildings has increased substantially. Mass timber buildings possess several advantages over concrete and steel high-rise buildings such as higher strength over weight ratio, architectural appeal, environmentally friendly materials, as well as competitive material cost. In addition, ease of modularization and offsite construction is one of the greatest advantages of constructing tall mass timber buildings in the congested urban areas of major cities.

In order to increase the versatility of mass timber products for use in high-rise buildings, it is necessary to understand, investigate, and finally overcome the challenges associated with building high-rise buildings using new materials. One of the main challenges, due in part to the lack of research available on this topic, is understanding the inherent structural robustness in the context of tall mass timber buildings before designing for additional requirements to mitigate the potential of disproportionate collapse.

This paper seeks to initiate the process of understanding the behaviour of mass timber components and systems and then make recommendations regarding their performance and possible methods for mitigating the impacts of a disproportionate collapse event. After a brief definition of the topic being investigated, ten major previous disproportionate collapse incidents are summarized. Lessons learned from past experience applicable to mass timber structures are also discussed. Based on the historical discussion provided, ten recommendations are put forth that can be used by design practitioners who intend to consider timber as the main structural material for their next high-rise building. These recommendations can lead to a more economical design and safer structural mass timber systems in the event of localized damage that has the potential to spread to a disproportionately large part of the structure.

\section{PROGRESSIVE COLLAPSE}

\section{DEFINITION}

Disproportionate collapse is defined by a cascading progression of failure that is not proportionate to the first local damage. When a load-bearing member of a building, mainly a column or wall, is eliminated, called "column removal scenario" (CRS), due to different hazards, the internal forces in the adjacent structural components increase in order to redistribute the supported forces. If the appended internal forces caused by local damage cannot be redistributed, partial or total collapse of the building happens (Song and Sezen 2009). This phenomenon is illustrated in Figure 1. The hazards mentioned above can be natural or manmade. Terrorist attacks, accidental explosions, vehicular impact, design and construction flaws, fire, and extreme environmental loading (e.g., an earthquake) can trigger disproportionate collapse (Daneshvar 2013).

The General Services Administration (GSA) defines progressive collapse "as an extent of damage or collapse that is disproportionate to the magnitude of the initiating event" (GSA 2013). The guideline definition focuses on the aftermath of the collapse rather than the phenomenon itself; therefore, it was suggested to use the term "disproportionate" instead of the widely used "progressive" collapse. This terminology is adopted herein. American Society of Civil Engineers (ASCE) 7 defines progressive collapse as "the spread of an initial local failure from element to element, eventually resulting in the collapse of an entire structure or a disproportionately large part 
of it" (ASCE 2015). As observed, the phenomenon under consideration is versatile because it may occur in all types of structures regardless of material or system. However, due to greater consequences, it is more important in high-rise buildings.

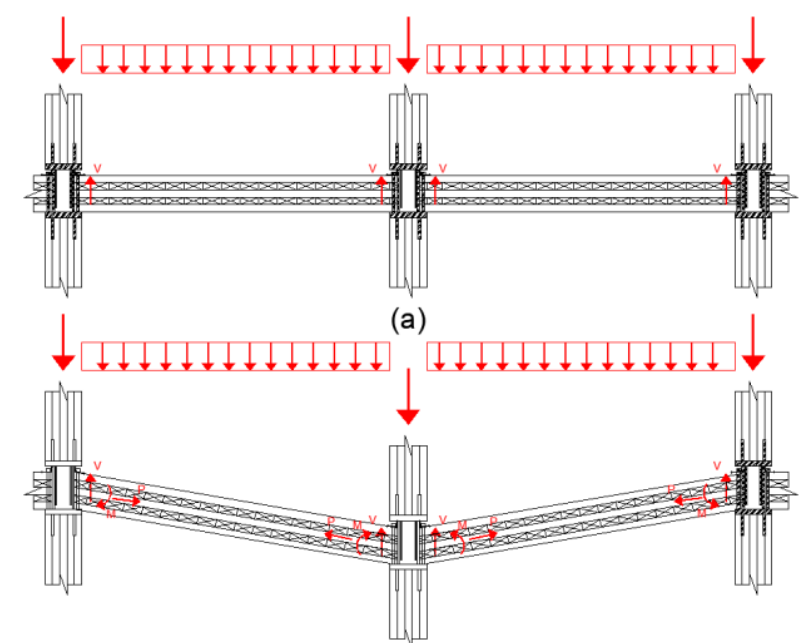

(b)

Figure 1. Column removal scenario: common case of disproportionate collapse evaluation

\section{HISTORY}

Disproportionate collapse has been considered of great significance in both engineering research and practice communities interested in characterizing the failure of high-rise buildings immediately after the Ronan Point collapse (Griffiths 1968). After that, disproportionate collapse had not received the same level of attention during the following decades. The terrorist attack of the World Trade Center Towers in 2001 has reignited the interest in progressive collapse. This event caught the attention of practitioners and researchers and there is a genuine interest to advance this research area (Daneshvar 2013).

Table 1 introduces ten major case studies of disproportionate collapse. As can be seen, regardless of threats, the structural system for almost all the buildings under consideration is concrete and steel. It reflects the fact that most of the mid-rise and high-rise buildings built during last few decades were made of steel and concrete. One might interpret this observation as a lack of information on general structural integrity of mass timber building. However, there are valuable lessons that can be learned. Table 2 discusses the initial failure, the consequence, and finally the lessons learned from such incidents that are applicable to high-rise mass timber buildings and that might have mitigated the catastrophic events.

A quick survey in the available literature reveals that the current body of knowledge is very limited with respect to the performance of mass timber buildings in disproportionate collapse scenarios. Also, the current building codes are still in their infancy when it comes to the structural integrity of such structures. As the construction industry is moving towards using mass timber to construct high-rise buildings, the probability of disproportionate collapse failure in such buildings will be increased as well. There are intricacies involved both in terms of individual timber components as well as assembly of components that need to be studied analytically as well as experimentally. In general, disproportionate collapse is not a frequent event; however, due to the catastrophic 
consequences involved its occurrence, it needs to be taken into consideration during the design process.

Table1. A quick glance at ten selected major historical cases of disproportionate collapse incidents (adapted from Daneshvar 2013)

\begin{tabular}{|c|c|c|c|c|c|c|}
\hline $\begin{array}{l}\text { Case } \\
\text { No. }\end{array}$ & $\begin{array}{l}\text { Building } \\
\text { Name }\end{array}$ & $\begin{array}{l}\text { Building } \\
\text { Location }\end{array}$ & Structural system & Year & Threat & Reference \\
\hline 1 & Ronan Point & $\begin{array}{l}\text { Newham, } \\
\text { England }\end{array}$ & $\begin{array}{l}\text { precast concrete } \\
\text { panel }\end{array}$ & 1968 & gas explosion & (Nair 2003) \\
\hline 2 & Skyline Plaza & $\begin{array}{l}\text { Kansas City, } \\
\text { USA }\end{array}$ & $\begin{array}{l}\text { reinforced concrete } \\
\text { flat plate type }\end{array}$ & 1973 & $\begin{array}{l}\text { construction defect - } \\
\text { debris shedding }\end{array}$ & $\begin{array}{c}\text { Source: } \\
\text { http://www.nyti } \\
\text { mes.com/2008/0 } \\
\text { 7/27/us/27hyatt. } \\
\text { html }\end{array}$ \\
\hline 3 & $\begin{array}{c}\text { Hyatt } \\
\text { Regency } \\
\text { Hotel } \\
\text { Skywalks }\end{array}$ & $\begin{array}{c}\text { Kansas } \\
\text { City, USA }\end{array}$ & $\begin{array}{c}\text { pedestrian } \\
\text { walkways } \\
\text { constructed of } \\
\text { structural steel } \\
\text { suspended by steel } \\
\text { rods }\end{array}$ & 1981 & crowd & (Crowder 2005) \\
\hline 4 & $\begin{array}{l}\text { L'Ambiance } \\
\text { Plaza }\end{array}$ & $\begin{array}{l}\text { Bridgepart, } \\
\text { Connecticut }\end{array}$ & $\begin{array}{c}\text { post-tensioned } \\
\text { concrete slab } \\
\text { supported on steel } \\
\text { columns }\end{array}$ & 1987 & construction defect & (NIST 2007) \\
\hline 5 & $\begin{array}{l}\text { Alfred P. } \\
\text { Murrah } \\
\text { Federal } \\
\text { Building } \\
\end{array}$ & $\begin{array}{l}\text { Oklahoma } \\
\text { City, } \\
\text { Oklahoma }\end{array}$ & $\begin{array}{l}\text { reinforced concrete } \\
\text { OMRF one way } \\
\text { slab system }\end{array}$ & 1995 & bomb explosion & (NIST 2005) \\
\hline 6 & $\begin{array}{l}\text { Khobar } \\
\text { Towers }\end{array}$ & $\begin{array}{c}\text { Alkhobar, } \\
\text { Saudi Arabia }\end{array}$ & $\begin{array}{l}\text { precast concrete } \\
\text { wall and floor }\end{array}$ & 1996 & bomb explosion & (NIST 2005) \\
\hline 7 & $\begin{array}{l}\text { WTC } 1 \text { and } \\
\text { WTC } 2\end{array}$ & $\begin{array}{l}\text { New York, } \\
\text { USA }\end{array}$ & $\begin{array}{c}\text { frame-tube concept } \\
\text { including exterior } \\
\text { wall, the core, the } \\
\text { floor system and the } \\
\text { hat truss }\end{array}$ & 2001 & airplane crash & (NIST 2005) \\
\hline 8 & WTC 7 & $\begin{array}{l}\text { New York, } \\
\text { USA }\end{array}$ & $\begin{array}{l}\text { braced frames with } \\
\text { transfer truss and } \\
\text { transfer girders }\end{array}$ & 2001 & flaming debris & (NIST 2007) \\
\hline 9 & Pentagon & $\begin{array}{l}\text { Arlington, } \\
\text { Virginia, } \\
\text { USA } \\
\end{array}$ & $\begin{array}{l}\text { cast-in-place } \\
\text { reinforced concrete }\end{array}$ & 2001 & airplane crash & (NIST 2005) \\
\hline 10 & $\begin{array}{c}\text { Bankers } \\
\text { Trust } \\
\text { Building } \\
\text { (Deutsche } \\
\text { Bank) } \\
\end{array}$ & $\begin{array}{l}\text { New York, } \\
\text { USA }\end{array}$ & $\begin{array}{l}\text { forty-storey steel } \\
\text { structure-ordinary } \\
\text { moment frame in } \\
\text { both direction }\end{array}$ & 2001 & debris shedding & (NIST 2007) \\
\hline
\end{tabular}


Table2. Initial damage, consequence and lesson learned from disproportionate collapse incidents discussed in Table 1 (adapted from Daneshvar 2013)

\begin{tabular}{|c|c|c|c|}
\hline $\begin{array}{l}\text { Case } \\
\text { No. }\end{array}$ & Initial Damage & Consequence & Lesson learned \\
\hline 1 & $\begin{array}{l}\text { Failure of precast exterior } \\
\text { concrete wall at the } 18^{\text {th }} \text { storey }\end{array}$ & $\begin{array}{l}\text { Collapse of the entire corner } \\
\text { of the building }\end{array}$ & $\begin{array}{l}\text { Structure should possess alternate load } \\
\text { path for distributing forces after loss of a } \\
\text { bearing wall or column. }\end{array}$ \\
\hline 2 & $\begin{array}{l}\text { Premature removal of the } \\
\text { shoring on the } 22 \text { th floor while } \\
\text { placing concrete on } 24^{\text {th }} \text { floor }\end{array}$ & $\begin{array}{l}\text { Punching shear failure of the } \\
\text { slab around columns at the } \\
23^{\text {th }} \text { floor and consequently, } \\
\text { full height collapse of the } \\
\text { building. Impact of debris } \\
\text { also caused the collapse of } \\
\text { garage under construction } \\
\text { next to the tower. }\end{array}$ & $\begin{array}{l}\text { Disproportionate collapse should be } \\
\text { considered not only during the design } \\
\text { process, but also during construction. } \\
\text { Providing stability of the structure (e.g., } \\
\text { bracing as needed) is necessary. }\end{array}$ \\
\hline 3 & Failure of single connection & $\begin{array}{l}4^{\text {th }} \text { floor walkway collapsed } \\
\text { onto the } 2^{\text {nd }} \text { floor walkway }\end{array}$ & $\begin{array}{l}\text { Statically determinate system with no } \\
\text { redundancy and no ability to develop } \\
\text { alternate load path should be avoided. All } \\
\text { the connection details should be verified } \\
\text { in terms of the ability of the connection to } \\
\text { sustain induced catenary forces. }\end{array}$ \\
\hline 4 & $\begin{array}{l}\text { Sudden loss of support for one } \\
\text { or more slabs }\end{array}$ & $\begin{array}{l}\text { Entire collapse of both wings } \\
\text { of the building }\end{array}$ & $\begin{array}{l}\text { The stability of the structure during } \\
\text { construction is as important as the } \\
\text { stability after completion of the whole } \\
\text { building. }\end{array}$ \\
\hline 5 & $\begin{array}{l}\text { Failure of columns supporting } \\
\text { the transfer girder }\end{array}$ & $\begin{array}{l}\text { Collapse of all the floors } \\
\text { above the transfer girder }\end{array}$ & $\begin{array}{l}\text { Transfer girder supporting wide area } \\
\text { above should be avoided. Providing } \\
\text { continuity, redundancy, and ductility are } \\
\text { the key factors. }\end{array}$ \\
\hline 6 & $\begin{array}{l}\text { The façade wall of the closest } \\
\text { building and some interior } \\
\text { floor and wall components } \\
\text { were damaged. }\end{array}$ & $\begin{array}{l}\text { Collapse did not spread out } \\
\text { much beyond the affected } \\
\text { area }\end{array}$ & $\begin{array}{c}\text { Ductility in all components of the } \\
\text { structure, particularly the connections, } \\
\text { assist in mitigating the disproportionate } \\
\text { collapse effect. }\end{array}$ \\
\hline 7 & $\begin{array}{c}\text { Structural members are } \\
\text { severely damaged on several } \\
\text { upper floors of the buildings. }\end{array}$ & $\begin{array}{c}\text { Fire ensued, and } \\
\text { consequently, the whole } \\
\text { structures collapsed. }\end{array}$ & $\begin{array}{l}\text { Enhancing the structural integrity and fire } \\
\text { endurance are recommended by the } \\
\text { investigators. }\end{array}$ \\
\hline 8 & $\begin{array}{l}\text { Failure of some columns due to } \\
\text { impact of debris or exposing to } \\
\text { fire }\end{array}$ & Global collapse & $\begin{array}{l}\text { Structural integrity needs to be considered } \\
\text { at the design level to prevent } \\
\text { disproportionate collapse in case local } \\
\text { damage happens. }\end{array}$ \\
\hline 9 & $\begin{array}{l}\text { About fifty columns on the first } \\
\text { floor were removed }\end{array}$ & $\begin{array}{l}\text { Relatively small portion of } \\
\text { the affected area collapsed but } \\
\text { only after sufficient time for } \\
\text { excavating. }\end{array}$ & $\begin{array}{l}\text { Providing redundancy and alternate path } \\
\text { loads can mitigate the disproportionate } \\
\text { collapse significantly. }\end{array}$ \\
\hline 10 & $\begin{array}{l}\text { Debris from South WTC tower } \\
\text { impact the } 23^{\text {rd }} \text { floor of the } \\
\text { building }\end{array}$ & $\begin{array}{l}\text { Although the vertical column } \\
\text { destroyed between } 18^{\text {th }} \text { and } 9^{\text {th }} \\
\text { floors, no further damage } \\
\text { greater than what was caused } \\
\text { by debris collision reported. }\end{array}$ & $\begin{array}{l}\text { Structure should be able to redistribute the } \\
\text { loads to remain stable. }\end{array}$ \\
\hline
\end{tabular}




\section{RECOMMENDATIONS TO MITIGATE DISPROPORTIONATE COLLAPSE}

In this section, ten recommendations are highlighted for practicing engineers to consider when designing mass timber structures to avoid disproportionate collapse scenarios. Although the recommendations are general and can be applied to all building with different VLRSs and LLRSs, they are mainly considered for two common structural types. Figure 2 (a) and (b) show two common VLRS and the associated connections used in the Brock Commons building and the Glenora West Block 300 located in Vancouver and Edmonton, respectively. Disproportionate collapse is considered an ultimate limit state; hence, it is expected that the mass timber components, whether they are glulam or CLT, behave mainly in an elastic manner and all the nonlinear deformation happens at the location of the connections. As a result, connections are playing a very important role in the structural integrity of mass timber systems. The key connection in the Brock Commons building are the column-to-column connections made of hallow structural steel (HSS). For the Glenora building, the key connection is a monolithic U-shaped bent plate screwed to supported beams as well as the column above.

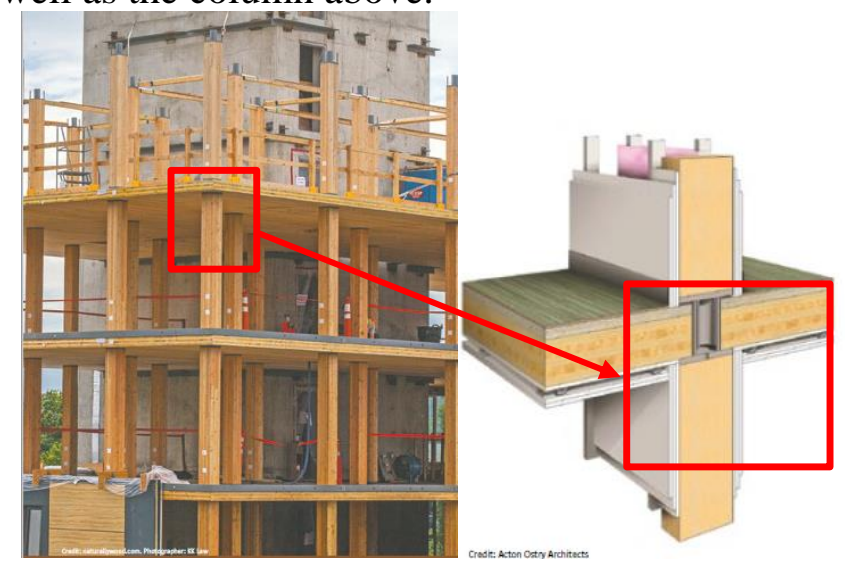

(a)

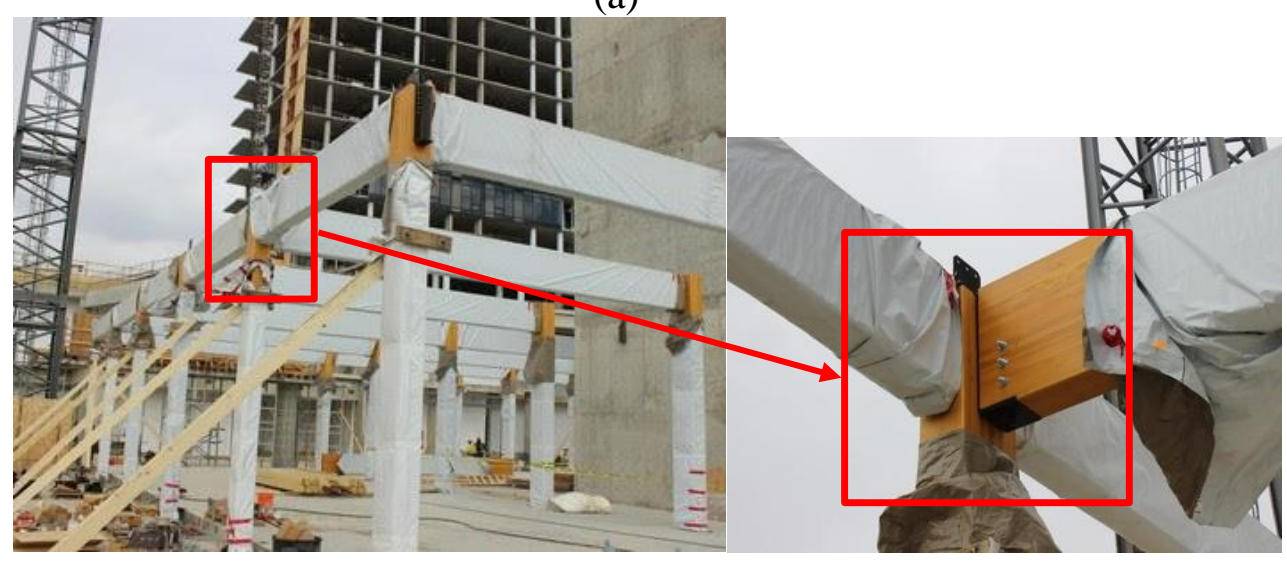

(b)

Figure 3. (a) Glulam column - CLT diaphragm VLRS and sample connection in the Brock Commons Building (Courtesy of FAST \& EPP/Source: Woodworks \& CWC) (b) the Glenora West Block 300 building and sample frame beam-column VLRS connection (Courtesy of Beam Craft: https://www.beamcraft.ca/projects/project/westblock)

Below are ten recommendations to mitigate disproportionate collapse in mass timber buildings considering the structural systems shown in Figure 3: 
1- Reduce the probability of local failure: The first and the most practical method to prevent disproportionate collapse failure in the structure, although it is not a relatively inexpensive approach, is to avoid initial local failure. Different causes that trigger disproportionate collapse have been mentioned earlier; however, the one that is of importance in high-rise timber building is fire. Most of the methodologies designed to mitigate disproportionate collapse are threat-independent. However, for high-rise mass-timber building, a threat-dependant method specifically designed for fire is encouraged considering the consequences. Using gypsum boards, sprinklers, and access roads all reduce the potential threat without altering the structural system. Considering additional thickness for the main members to satisfy fire section analysis is also suggested.

2- Increase connection ductility: Regardless of the structural system employed for both VLRS as well as LLRS, connections are the main source of ductility in mass timber buildings. It is suggested to design ductile connections for VLRS as well as LLRS due to the possibility of member loss in both. It is noted that the connection behaviour under gravity and seismic loads is different than in CRS, which is the common case in disproportionate collapse. In general, using slender fasteners such as nails, wood screws, and timber rivets will potentially lead to ductile connections. It is suggested to avoid details that result in tension perpendicular to grain due to potential brittle failure.

3- Provide good structural plan layout: A good structural plan is always helpful despite the stringent architectural requirements. Examples of good engineering practice in outlining a well-designed structural plan for collapse prevention include the following: providing returns on CLT walls; changing the direction of GLT/CLT spans (assuming one-way action for CLT); avoiding using transfer glulam beams supporting large areas; and taking advantage of loadbearing interior partitions as necessary.

4- Design for induced axial force (catenary/membrane action): Regardless of the type of VLRS, compromising a vertical load bearing member will induce an axial force in the vicinity of the removed member. This induced tensile force, called catenary force in beams and membrane action in floors, should be accounted for in the design as shown in Figure 1.

5- Provide redundant alternate load paths: Considering several additional load paths in the VLRS of the structure in case one primary structural member is compromised can help considerably to survive a local damage without extending to the rest of the structure.

6- Consider sufficient strength and stability during construction and life-long operational stages: Structural integrity of the structure during construction is as important as its robustness during operation. Mechanical properties of timber materials are highly dependent on moisture condition. Loading direction relative to wood grain should be considered at each stage.

7- Compartmentalization: This methodology is considered for several reasons such as thermal (designing expansion joints) or seismic reasons for regularization. Disproportionate collapse might be another reason to consider compartmentalization during the design development process. Modularization provides a unique opportunity for compartmentalization in mass timber structures.

8- Consider the dynamic nature: As the vertical load-bearing component of a mass timber structure, i.e., wall or column, is compromised, an axial tensile wave will be produced travelling vertically along the column line or walls. The amplitude of axial tensile wave is dependent on the magnitude of removed compressive force, which is amplified due to sudden CRS called dynamic effect. The axial tensile wave may progressively cause failure of steel splice or wall connection to the diaphragm at each storey level. It is suggested to design the 
affected connections with appropriate impact load factor (minimum factor of 2) in lieu of advanced non-linear dynamic analysis.

9- Consider the reverse loading: It is good practice to design primary structural members of both VLRR as well as LLRR to be capable of resisting reverse loading at potential susceptible locations to increase robustness.

10-Provide vertical and horizontal ties: Providing ties, whether peripheral, vertical, or horizontal, is an effective way to provide robustness to mass timber structure. This goal can be achieved through the components that are initially designed for other purposes, e.g., taking advantage of drag struts designed to collect seismic induced forces through the diaphragm as horizontal tie.

\section{CONCLUSION}

Disproportionate collapse of mass timber buildings has not been reported in the literature so far, unlike steel and concrete high-rise buildings. However, as the number of these tall wood structures increases, the probability of such incidents rises; necessitating the need to consider the phenomenon during the design and construction stages. This paper provides ten recommendations, based on experience with steel and concrete buildings, for the designers to consider as a means to enhance the structural robustness of mass timber buildings.

\section{ACKNOWLEDGEMENTS}

The authors would like to acknowledge the support of the Natural Sciences and Engineering Research Council of Canada (NSERC), through the Industrial Research Chair program.

\section{REFERENCES AND CITATIONS}

ASCE. (2010). "ASCE/SEI7-10: Minimum Design Loads of Buildings and Other Structures." American Society of Civil Engineers, Reston, VA.

Crowder, B. (2005). "Progressive collapse - Historical Perspective." Presentation by Naval Facilities Engineering Command.

Daneshvar (2013). "Single sided steel shear connections in column removal scenario." $\mathrm{PhD}$ thesis, University of Alberta, Edmonton, AB.

Griffiths, H. P. (1968). "Report of the inquiry into the collapse of flats at Ronan Point, Canning Town." Ministry of Housing and Local Government, London, UK.

GSA. (2003). "Progressive collapse analysis and design guidelines for new federal office buildings and major modernization projects." U.S. General Services Administration, Washington, DC.

Nair, R. S. (2003). "Progressive collapse basics. Steel Building Symposium: Blast and Progressive Collapse Resistance." Blast and Progressive Collapse Symposium, American Institute of Steel Construction and the Steel Institute of New York, New York, NY.

NIST. (2005). "Final report on the collapse of world trade center towers." NIST NCSTAR 1: National institute of standards and technology. Gaithersburg, MD.

NIST. (2007). "Best Practices for Reducing the Potential for Progressive Collapse in Buildings." National Institute of Standards and Technology. Gaithersburg, MD.

Woodworks and CWC. "Brock Commons Tallwood House - University of British Colombia Vancouver Campus The advent of tall wood structures in Canada: A case Study". 